\title{
PEMBAHARUAN DALAM TASAWUF
}

\section{(STUDI TERHADAP KONSEP NEO-SUFISME FAZLURRAHMAN)}

\author{
Oleh: Tita Rostitawati
}

\begin{abstract}
Abstrak
Fazlur Rahman sesungguhnya menghendaki agar umat Islam mampu melakukan tawazun (keseimbangan) antara pemenuhan kepentingan akhirat dan kepentingan dunia, serta umat Islam harus mampu memformulasikan ajaran Islam dalam kehidupan sosial. Kebangkitan kembali tasawuf di dunia Islam dengan istilah baru yaitu neo-sufisme nampaknya tidak boleh dipisahkan dari apa yang disebut sebagai kebangkitan agama. Kebangkitan ini juga adalah lanjutan kepada penolakan terhadap kepercayaan yang berlebihan kepada sains dan teknologi selaku produk dari era modenisme. Modernisme telah dinilai gagal memberikan kehidupan yang bermakna kepada manusia. Oleh karena itu, manusia telah kembali kepada nilai-nilai keagamaan karena salah satu fungsi agama adalah memberikan makna bagi kehidupan. Demikianlah, era post-modernisme yang dibelenggu dengan bermacam-macam krisis yang semakin parah dalam berbagai aspek kehidupan. Akhlak masyarakat semakin buruk dan kejahatan semakin banyak. Kebangkitan nilai-nilai keagamaan tidak salah lagi telah menggerakkan kembali upaya menghidupkan karya-karya klasik dengan pendekatan baru termasuk juga dalam bidang tasawuf. Karya-karya dalam bidang tasawuf yang dihasilkan oleh penulis kontemporer seperti al-Taftazani menunjukkan adanya garis lurus untuk menegaskan kembali bahwa tradisi tasawuf tidak pernah lepas dari akar Islam. Ini menunjukkan bahwa kebangkitan tasawuf kontemporer ditandai dengan pendekatan yang sangat pesat antara spiritualisme tasawuf dengan konsep-konsep Syariah. Tasawuf yang dianut dan dikembangkan oleh sufi kontemporer nampaknya berbeda dari sufisme yang difahami oleh kebanyakan orang selama ini yaitu sufisme yang hampir lepas dari akarnya (Islam), cenderung bersifat memisah atau eksklusif. Menurut mereka, sufisme yang berkembang kebelakangan ini, sebagaimana dinyatakan oleh Akhbar S Ahmed, pascamodernisme membawa kita kepada kesadaran betapa pentingnya nilai keagamaan dan keperluan terhadap toleransi serta perlunya memahami orang lain yang semuanya terdapat dalam neosufisme.
\end{abstract}

Kata kunci: Tasawuf, Neo-Sufisme, Fazlurrahman 
FARABI

Jurnal Pemikiran Konstruktif Bidang Filsafat dan Dakwah

ISSN $1907-0993$

E ISSN $2442-8264$

Vol. 18 No. 2, Desember 2018

\section{A. PENDAHULUAN}

Dampak era modernitas saat ini mereduksi seluruh esensi dalam perngertian metafisik dan peran agama, kepada material dan subtansial. Dengan demikian, pandangan agama nyaris sirna dalam era modern saat ini. Namun bersamaan dengan hal itu, muncul satu femomena yang mencuat kepermukaan kehidupan modern adalah bangkitnya dimensi spiritualitas. Adalah suatu kenyataan bahwa spiritualitas semakin mendapat tempat tersendiri dalam masyarakat modern dewasa ini. Fenomena keagamaan ini sangat menarik untuk dicermati, karena akhir-akhir ini terdapat pula kecenderungan "rekonsiliasi" antara nilai sufistik dengan dunia modern. Ada kecenderungan baru bahwa dimensi spritualitas yang bersumber dari agama mulai dilirik kembali oleh masyarakat Barat karena kemajuan yang telah mereka peroleh dalam bidang iptek membuktikan bahwa problema yang muncul kemudian akibat kemajuan dunia global tetap saja belum terpecahkan. Kegagalan manusia modern ternyata oleh para pengamat dan khususnya futurology hampir sepakat mengatakan bahwa krisis besar yang melanda umat manusia tidak akan dapat diatasi dengan keunggulan iptek sendiri dan kebesaran ideology yang dianut oleh Negara-negara terkemuka. Ideologi sosialisme komunisme misalnya telah gagal total. Ideologi besar lainnya seperti kapitalisme liberalisme juga dianggap goyah dan rapuh, tinggal menunggu lonceng kematiannya. Di sinilah agama dilirik sebagai harapan dan benteng terakhir untuk menyelamatkan manusia dari kehancuran yang mengerikan. ${ }^{1}$

Antusias masyarakat dalam mencari kebutuhan spiritualitas itu, ditandai dengan adanya kajian-kajian intens keagamaan yang menjawab kegersangan hati. Ilmu tasawuf mulai digandrungi kembali, hingga banyak bermunculan "tarekat" pada masa ini terutama di wilayah perkotaan. Namun tidak bisa dipungkiri bahwa tasawuf mengalami inovasi baru guna menjawab tantangan era modern. Kemampuan tasawuf untuk beradaptasi itulah menjadikan munculnya apa yang sering di sebut dengan Neo-Sufisme. Munculnya Neo-sufisme dalam dunia Islam tidak luput dari adanya kebangkitan agama yang menolak terhadap kepercayaan yang berlebihan kepada sains dan teknologi selaku produk era modernisme. Modernisme telah dinilai gagal dalam mengantarkan kehidupan manusia lebih baik, yang penuh dengan kepedulian dan menebarkan kasih sayang, atau bahkan efek dari modernisme tidak lagi memanusiakan manusia sebagaimana layaknya manusia adanya, justru modernisme menjauhkan kehidupan yang bermakna bagi manusia itu sendiri, maka banyak orang yang

\footnotetext{
${ }^{1}$ Said Agil Husain Al-Munawar, Al-Quran Membangun Tradisi Kesalehan Hakiki (Cet. III; Jakarta: Ciputat Press, 2004), h. 374.
} 
$F A R A B I$

Jurnal Pemikiran Konstruktif Bidang Filsafat dan Dakwah

ISSN $1907-0993$

E ISSN $2442-8264$

Vol. 18 No. 2, Desember 2018

kembali pada agama sebagai institusi religiusitas. Era modern harus merapat pada agama yang mampu menjamin kehidupan penuh makna.

Sufisme terdahulu mencoba mengungkapkan melalui pendekatan batin, kesan dari pendekatan esoterik ini adalah disebabkan kepincangan dalam tindak tanduk nilai-nilai Islam yang lebih mengutamakan makna batiniah atau ketentuan yang tersirat saja tanpa memperhatikan aspek lahiriahnya. Oleh karena itu kaum sufi tidak tertarik untuk memikirkan masalah-masalah sosial kemasyarakatan, bahkan lebih tertumpu kearah peribadatan semata. Menghadapi realitas ini, pada awal abad ke XX, lahir pemikiran baru yang menginginkan tasawuf tidak berpola seperti yang telah diuraikan diatas, dalam pandangan mereka tasawuf harus positif dalam memandang kehidupan dunia, tidak boleh menjauhinya dan justru harus berperan aktif di dalamnya. Gerakan ini mempunyai berbagai istilah seperti Tasauf Modern, Urban Sufisme, Sufisme Kontemporer dan Neo-Sufisme (selanjutnya dalam tulisan ini penulis memakai istilah Neo-Sufisme. ${ }^{2}$

Gejala ini juga bisa dikatakan sebagai pembaharuan dalam dunia sufisme, menurut Azyumardi Azra khusus untuk Indonesia hal ini terjadi akibat berbagai permasalahan agama, sosial, politik, ekonomi dan budaya yang kompleks. Selain itu keadaan ekonomi yang mapan mendorong umat Islam tidak hanya beribadah namun mengekplorasi pengalaman keagamaan dan spritualitas yang intens dan hanya didapat dari sufisme yang tidak selalu sesuai dengan paradigma dan bentuk tasawuf konvensional ${ }^{3}$ Konsep neo-sufisme Fazlurrahman sesungguhnya menghendaki agar umat Islam mampu melakukan tawazun atau keseimbangan, yaitu keseimbangan antara kehidupan dunia dan kehidupan akhirat, antara kesalihan individu dan kesalihan sosial

\footnotetext{
${ }^{2}$ Kasmuri selamat dan Ihsan Sanusi, Akhlak Tasawuf: Upaya Meraih Kehalusan Budi dan kedekatan Ilahi Jakarta Kalam Mulia,2012), h.203

${ }^{3}$ Martin dan Julia, Urban Sufism, (Jakarta : Raja Grafindo Persada, 2008), h. 5
} 
FARABI

Jurnal Pemikiran Konstruktif Bidang Filsafat dan Dakwah

ISSN $1907-0993$

E ISSN $2442-8264$

Vol. 18 No. 2, Desember 2018

\section{B. PEMBAHASAN}

\section{Biografi Fazlur Rahman}

Fazlurrahman dilahirkan di Hazara, Fakistan pada tanggal 21 September 1919. Ia berasal dari keluarga muslim yang amat religius, taat dan teratur dalam menjalankan kewajiban agamanya. Keluarga Fazlur Rahman adalah keluarga yang sangat patuh terhadap tradisi Hanafi, suatu permulaan yang sangat kondusif bagi perkembangan pemikirannya. Kedua orang tuanya merupakan pribadi-pribadi yang memiliki pandangan modern dalam menghadapi kehidupan sosial dan hidup di tengah-tengan masyarakat yang masih banyak di antara kaum cendekiawannya beranggapan bahwa pendidikan modern merupakan racun bagi agama dan moralitas.

Ayahnya Maulana Syahab ad-Din adalah seorang ,alim yang memiliki pemikiran Islam tradisional, namun mampu memandang pendidikan modern dan modernitas sebagai tantangan dan kesempatan, bukan sebagai racun bagi keimanan. Maulana adalah lulusan Daral-,,Ulum yang pandangannya tentang kebebasan berfikir banyak mempengaruhi FazlurRahman.

Ia memperoleh pendidkan formal dari Madrasah, namun juga mendapatkan pelajaran keagamaan dari ayahnya. Pada tahun 1933 keluarga Fazlur Rahman pindah dari Pakistan ketanah leluhurnya di wilayah yang kini terletak di tepi Barat Laut Pakistan yaitu Lahore. Di Lahore Rahman belajar di sebuah sekolah modern disamping menuntut ilmu disekolah tersebut, di rumah ia mendapatkan pelajaran-pelajaran tradisional dalam kajiankajian keislaman.

Setelah menamatkan pendidikan menengahnya Rahman melanjutkan studinya di Departemen Ketimuran Universitas Punjab Lahore dan berhasil meraih gelar B.A dan M.A. dalam bidang bahasa Arab, masing-masing pada tahun 1942 dan 1944. Ia sempat pula mengikuti program doctor sampai 1946. Ketika ia sedang menempuh gelar doktornya ia

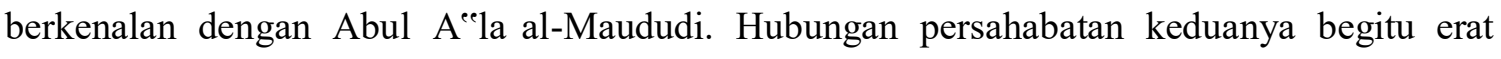
sehingga pada suatu saat al-Maududi mengajak Rahman untuk bergabung dalam Jama "eat Islami dengan syarat Rahman harus meninggalkan studinya. Karena menurut Abul A"la Maududi semakin banyak belajar akan semakin beku kemampuan-kemampuan praktisnya. Akan tetapi Rahman dengan tegas menolak ajakan tersebut, ${ }^{4}$ dan bahkan ia menjadi seorang kritikus yang sangat tajam terhadap pemikiran-pemikiran keagamaan Maududi.

${ }^{4}$ Fazlur Rahman, Islam and Modernity: Tranformation of an Intellectual Tradition (Chicago and London:University of Chicago Press, 1982), h.117. 
Didorong rasa ketidakpuasan terhadap kualitas pendidikan di India yang sangat jauh dari harapannya, maka Rahman pergi ke Inggris dengan tujuan melanjutkan studi pasca sarjananya di Oxford University, sampai berhasil mendapatkan gelar doctor pada tahun 1949 dengan disertasinya Avicennae s Psychology. Kehidupan akademis di Inggris ia manfaatkan untuk belajar beragam bahasa hingga ia berhasil menguasai bahasa Inggris, Latin, Yunani, Prancis, Jerman, Turki, Arab, Persia, selain Urdu sebagai bahasa ibu. Bagian terpenting adalah interaksinya dengan dunia rasionalisme di Barat yang semakin berkembang. Berbicara tentang alur pemikiran Rahman ada dua istilah metodik yang sering disebutkan dalam bukunya: historico-critical method (metode kritik sejarah) dan hermeunetic method (me-tode hermeunetik). Kedua istilah tersebut merupakan kata kunci untuk menelusuri metode-metode dalam pemikirannya.

Setelah berhasil menyelesaikan studinya di Oxford, Fazlur Rahman lantas tidak pulang kampung. Ia memilih untuk berkarir akademis di Durham University sebagai dosen bahasa Persia dan Filsafat Islam (1950-1958) dan kemudian hijrah ke Kanada untuk menjadi Associate Professor pada kajian Islam di Institute Of Islamic Studies McGill University Kanada di Montreal, ${ }^{16}$ di mana dia menjabat sebagai Associate Professor of Philosophy. Mengiringi tampuk pemerintahan Pakistan yang dipengang oleh Ayyub Khan yang berpandangan modern, Fazlur Rahman pulang ke kampung halamannya dan berniat untuk membenahi negerinya. Di sana Fazlur Rahman menghadapi perdebatan antara tiga kelompok besar: tradisionalis, fundamentalis, dan modernis. Di Pakistan Rahman menjabat sebagai direktur Central Institute of Islamic Research (Pusat Lembaga Riset Islam) dan Advisory Council of Islamic Ideology (Dewan Penasihat Ideologi Islam).

Selama memangku jabatan tersebut, Fazlur Rahman mendapatkan kesempatan untuk memperkenalkan gagasan progresifnya dalam perdebatan-perdebatan yang telah ada. Gagasangagasannya, seperti yang berkenaan dengan kehalalan makanan yang disembelih dengan mesin, Hadis dan Sunnah, riba, bunga Bank, dan sebagainya, telah memicu kontroversi. Usaha Fazlur Rahman sebagai seorang pemikir modern ditentang keras oleh para ulama tradisional-fundamentalis. Puncak dari segala kontroversialnya memuncak ketika 2 bab karya momumen-talnya, Islam (1966) ditentang keras karena pernyataan Fazlur Rahman dalam buku tesebut "Bahwa Al-Qur'an itu secara keseluruhan adalah kalam Allah dan dalam pengertian biasa juga seluruhnya merupakan perkataan Muhammad"s sehingga Fazlur 
Rahman dianggap orang yang memungkiri Al-Qurean. Merasa tidak nyaman akan hal itu pada 5 September 1968 Rahman mengundurkan diri dari jabatan Direktur lembaga Riset Islam yang langsung di kabulkan oleh Ayyūb Khān.

Mengiringi penentangan yang semakin memuncak dari kalangan tradisionalisfundamentalis, menjelang akhir 1968 Fazlur Rahman mendapat tawaran untuk mengajar di Universitas California, Los Angeles. Seketika itu, ia dan keluarganya ke sana. Berselang satu tahun, ia diangkat menjadi Guru Besar Pemikiran Islam di Universitas Chicago. Di sana, ia menyerahkan seluruh hidupnya untuk karir akademik. Ia menghabiskan sebagian besar waktunya di perpustakaan pribadinya yang bertempat di basement rumahnya di Naperville, kurang lebih 70 km dari University of Chicago. Beberapa saat sebelum wafat, Fazlur Rahman menyempatkan diri mengunjungi Indonesia (1985) dan tinggal selama 2 bulan, memperhatikan keberagamaan Islam Indonesia sekaligus memberikan kuliah di beberapa tempat. Akhirnya, pada tanggal 26 Juli 1988, Fazlur Rahman menghembuskan nafas terakhirnya di Chicago. ${ }^{6}$

Fazlur Rahman termasuk seorang cendekiawan yang produktif. Setidaknya terdapat lebih dari 5 buku (selain disertasi doktor) dan tidak kurang dari 50 artikel yang dimuat di beberapa jurnal Internasional. Disertasinya ketika di Oxford membahas Ibnu Sina, dan pada saat yang sama, ia menterjemahkan beberapa buku Ibnu Sina. Di antara karyanya adalah: Prophecy in Islam: Philosophy and Ortodoxy, The Philosophy of Mulla Sadra, Islamic Methodology in History yang telah diterjemahkan dalam bahasa Indonesia dengan judul: Membuka Pintu Ijtihad. Islam, Major Themes of Qur'an; Islam and Modernity: Transformation of an Intellecttual, dan sebagainya. ${ }^{7}$

\footnotetext{
${ }^{6}$ Abd A"la, Dari Neomodernisme ke Islam Liberal: Jejak di Indonesia (Jakarta: Paramadina, 2003), h. 39-43.

${ }^{7}$ Ghufron A. Mas"adi, Pemikiran Fazlur Rahman, h. 19-25

Fazlurrahman dalam Wacana Islam
} 
FARABI

Jurnal Pemikiran Konstruktif Bidang Filsafat dan Dakwah

ISSN $1907-0993$

E ISSN $2442-8264$

Vol. 18 No. 2, Desember 2018

\section{Pemikiran Fazlurrahman}

Istilah neo-sufisme terdiri dari dua kata neo dan sufisme. Neo berarti sesuatu yang baru atau yang diperbaharui. ${ }^{8}$ Sedangkan sufisme berarti nama umum bagi berbagai aliran sufi dalam agama Islam. Dengan demikian neo- sufisme dapat diartikan bentuk baru sufisme atau pembaruan sufisme dalam Islam. Menurut Fazlurrahman selaku penggagas istilah ini, neo-sufisme adalah Reformed Sufism, sufisme yang telah diperbaharui. ${ }^{9}$ Kemunculan istilah ini tidak begitu saja diterima para pemikir muslim, tetapi telah menjadikan perbincangan yang luas dalam kalangan para ilmuan. Sebelum Fazlur Rahman , Hamka telah memperkenalkan istilah tasawuf modern dalam bukunya Tasawuf Modern. Namun dalam keseluruhan isi buku ini terlihat wujud kesejahteraan prinsip-prinsipnya dengan tasawuf al-Ghazali kecuali dalam hal uzlah. Kalau al-Ghazali mensyaratkan uzlah dalam penjelajahan menuju konsep hakikat, dan cenderung menyendiri, maka Hamka menghendaki agar seseorang pencari kebenaran hakiki tetap aktif dalam berbagai aspek kehidupan bermasyarakat. $^{10}$

Dengan alasan ini dapat dikatakan, bahwa yang disebut neo sufisme itu tidak seluruhnya barang baru namun lebih tepat dikatakan sebagai sufisme yang diaktualisasikan dalam kehidupan pribadi dan masyarakat sesuai dengan kondisi kekinian. Seperti yang dikemukakan Burhani, Neo Sufisme dalam terminology Fazlurrahman atau tasawuf modern dalam terminology Hamka berusaha tetap mempertahankan hasil-hasil positif dari modernism. Kebangkitan kembali tasawuf di dunia Islam dengan istilah baru yaitu neosufisme nampaknya tidak boleh dipisahkan dari apa yang disebut sebagai kebangkitan agama. Kebangkitan ini juga adalah lanjutan kepada penolakan terhadap kepercayaan yang berlebihan kepada sains dan teknologi selaku produk dari era modernisme. Modernisme telah dinilai gagal memberikan kehidupan yang bermakna kepada manusia. Oleh karena itu manusia ramai kembali kepada nilai-nilai keagamaan karena salah satu fungsi agama adalah memberikan makna bagi kehidupan.

\footnotetext{
${ }^{8}$ Pusat Bahasa Departemen Pendidikan Nasional. Kamus Besar Bahasa Indonesia, (edisi III), (Jakarta: Balai Pustaka, 2005), h.779

${ }^{9}$ Fazlur Rahman Islam (terjemahan) Ahsin Muhammd, (Jakarta: Pustaka Bandung, 1984) h. 78-79

${ }^{10}$ Hamka, Tasawuf Modern, (Jakarta: Pustaka Panji Masyarakat, 1988), h.150.
} 
Untuk melacak pemikiran Rahman di bidang tasawuf, dapat diketahui dari pandangannya tentang perjalanan spiritual dalam Islam. Baginya spiritualisme itu telah ada semenjak Nabi Muhammad saw, dan ia sebagai penunjang misi kenabian dan kerasulannya, namun para sahabat tidak mempersoalkannya sebab mereka dituntut untuk melaksanakan segala perintah dan menjauhi segala laranganNya. Pengalaman spiritual dianggapnya sebagai kekhususan-nya. Dalam perkembangan selanjutnya penanaman taat terhadap hukum Tuhan. lama kelamaan menjadi tahapan khusus interiorisasi dan introspeksi motif moral, hal inilah yang menjadi landasan asketisme Islam yang berkembang dengan pesat pada abad VII dan VIII M.

Kehidupan asketisme awal kehi-dupan tasawuf yang merupakan reaksi atau protes moral spiritual dari keadaan pada waktu itu, yang akhirnya membawa sikap isolasi para sufi terhadap dunia, dan sikap sinisme politik akan menimbulkan pesimisme. Rahman sangat tidak sepakat dengan model kehidupan yang demikian, karena bertentangan dengan ajaran AlQuran, sebab yang utama dalam Al-Quran adalah implementasi aktual dari citra moral secara realistik dalam suatu kontek sosial. Justifikasi para sufi dengan kehidupan Nabi tidak bisa diartikan penolakan beliau terhadap dunia, akan tetapi sekedar menunjukkan kesederhanaan Nabi. Sebab bagaimanapun penolakan secara ekstrim terhadap kehidupan duniawi adalah salah satu hal yang sangat asing bagi Nabi

Rahman tidak sependapat dengan pandangan para tokoh tasawuf palsafi yang menurutnya mereka telah melakukan penambahan dalam agama. Karena esktase (Fana, baqa) yang dijalaninya telah menyebabkan pengisolasian diri yang dianggap sebagai perjalanan manusia menuju khaliknya. Penolakan Rahman tersebut berdasarkan pada perilaku Rasulullah. Menurutnya seandainya ekstase para sufi itu dianggap sebagai religious experience (pengalaman agama), maka Rasulullah pun mengalaminya. Tetapi pengalaman asketisme bukan sebagai titik akhir apalagi mengisolasikan diri dari kehidupan duniawi, melainkan tampil dalam bentuk social movement atau gerakan sosial. Sebab kesucian seseorang bukan karena keterasingannya dari dunia dan proses sosial, namun harus berada di dalamnya dalam bentuk gerakan menciptakan sejarah. Dengan demikian yang sebenarnya menjadi tujuan utama, al-Quran: yaitu tegaknya sebuah tata sosial yang bermoral, adil dan taqwa, konsep taqwa hanya memiliki arti dalam kontek sosialnya. ${ }^{11}$

\footnotetext{
${ }^{11}$ Fazlurrahman. Islam, h.54
} 
FARABI

Jurnal Pemikiran Konstruktif Bidang Filsafat dan Dakwah

ISSN $1907-0993$

E ISSN $2442-8264$

Vol. 18 No. 2, Desember 2018

\section{Latar belakang munculnya neo sufisme}

a. Adanya anggapan bahwa para sufi tidak peduli sama sekali dengan lingkungan, tidak peduli pada anak dan istri tidak mau berumah tangga dan sebagainya. Anggapan ini mengingatkan tentang eksistensi nabi dalam berbagai aspek kehidupan (sebagai ayah, suami panglima perang, kepala negara dan lain-lain) para sufi dinilai menampilkan corak kehidupan yang tidak seimbang dalam memenuhi kebutuhan jasmani dan rohani atau duniawi dan ukhtrawi.

b. Adanya anggapan bahwa para sufi mempunyai derajat khawas (elit/khusus) sedangkan selain mereka berada pada derajat awwam (umum). Maerifah mereka lebih tinggi dari ma"rifah lainnya, mahabbah mereka lebih tinggi dari mahabbah lain dari mereka. ${ }^{12}$ Klaim ini tidak diterima seutuhnya oleh ulama lainnya, sebab derajat tertinggi bagi mereka adalah corak kehidupan yang seimbang seperti yang dicontohkan oleh Rasulullah.

c. Adanya anggapan bahwa ittihad oleh Abu Yazid al-Bustami dan hulul oleh Abu Mansur Al-Hallaj, dinilai oleh kalangan ulama tidak logis mustahil terjadi dan bertentangan dengan ajaran Islam. ${ }^{13}$ Kritikan dan reaksi yang ditujukan kepada para sufi ini, mencapai puncaknya pada abad ke-3H. Sejumlah sufi yang hidup di abad ini dicap sebagai zindiq(kafir)

Dari beberapa faktor intern di atas, neo-sufisme juga muncul dipengaruhi oleh perkembangan peradaban Islam di abad pertengahan yang mengalami kemunduran, sehingga tasawuf berkembang dalam bentuk tarekat. Dengan demikian dalam era pertengahan ini yang berkembang bukan sufime tapi tarekat-tarekat. Ia sangat besar pengaruhnya dalam masyarakat Islam. Justru itulah menurut diagnose tokoh-tokoh pembaharu dalam Islam, seperti Jamaluddin al-Afghani, Muhammad Abduh dan Rayid Ridha bahwa tarekat sebagai salah satu faktor yang membawa kepada kemunduran umat Islam. Diagnosa tokoh-tokoh pembaharu ini tidak terlalu tepat, sebab berkembangnya agama Islam kebanyakan melewati jalur tarekat.

Neo-sufisme yang memiliki kecendrungan perhatiannya pada rekonstruksi sosialmoral masyarakat Islam sebagai kritik pada tasawuf lama yang cenderung individualis, dan hanya ukhrawi oriented sehingga mengakibatkan terkesan pasif. Maka keberadaan Neosufisme sangatlah berbeda, ia bersifat aktifis dan memiliki antusias terhadap kehidupan duniawi. Dalam konteks ini, aktifisme Neo-sufisme terlihat jelas pada banyak tokohnya yang berusaha melakukan perubahan dalam masyarakat Islam melalui anjuran kepada kaum

\footnotetext{
${ }^{12}$ Harun Nasution ensiklopedi Islam Indonesia (Jakarta Djembatan, 1992) h.601
} 
muslimin untuk berusaha, belajar, berkarya dan bekerja keras secara mandiri dari pada menunggu datangnya intervensi dan pertolongan eskatologis dari Tuhan. ${ }^{14}$ Sebagai contoh salah satu dalam jaringan ulama" Neo-sufisme Nusantara, al-Qusyasi (w. 1071 H), ia mengarahkan dan menganjurkan kaum muslimin untuk meninggalkan kemalasan dan kebodohan dengan menggunakan waktu sebaik-baiknya. Fungi kekhalifahan manusia harus dioptimalkan dalam rangka memenuhi kebutuhan jasmaniah dan rohaniah. Menurut alQusyasi, sufi sebenarnya bukanlah orang yang mengasingkan diri dari masyarakat, akan tetapi sufi adalah yang aktif melakukan amal ameeruf nahi munkar demi kemajuan dan kesejahteraan masyarakat. Dari ulasan di atas terlihat, bahwa gerak sejarah terhadap ranah neo-sufisme pada dasarnya adalah kelanjutan (contiunity) dari unsur penghayatan tradisi tasawuf lama yang ekstatis dan mistik-filosofis, kemudian diperbaharui dan dilakukan perubahan (change) sesuai dengan syariee ah dan relevan dalam menghadapi perubahan modernitas, khususnya watak aktif dan turut menjadi bagian menjadi solusi dalam kompleksitas problem masyarakat. ${ }^{15}$

\section{Karakteristik Neo Sufisme}

Menurut Fazlur Rahman, neo sufisme adalah “reformed Sufism”yang maksudnya adalah sufisme yang telah diperbaharui. ${ }^{16}$ Neo sufisme mengalihkan pusat pengamatan kepada pembinaan semua sosio-moral masyarakat muslim,sedangkan sufisme terdahulu didapati lebih bersifat individu dan hampir tidak melibatkan diri dalam hal-hal kemasyarakatan. Oleh karena itu, karakter keseluruhan neo-sufisme adalah "puritanis dan aktivis, puncak neo-sufisme bertujuan untuk memperkuat iman dengan pemikiraan amal shaleh dan mengabdi ke tengah masyarakat. Pengembangannya dilakukan oleh para ahl al-hadist

Karakter Dasar Neo-Sufisme Berdasarkan pada komentar para ahli dalam bidang tasawuf, yang membedakan neo-sufisme dibandingkan dengan sufisme lama adalah sebagai berikut: Pertama. menolak terhadap praktek tawawuf yang ekstrim dan ekstatis, seperti ritual dzikir yang diiringi tarian dan musik, atau praktek dzikir yang heboh dan tidak terkendali. Dengan demikian neo-sufisme terkesan agak menyederhanakan berbagai metode dan akspresi yang dilakukan sesuai dengan konsep syarieah. Kedua, menolak pemujaan yang berlebihan

\footnotetext{
${ }^{14}$ Nurcholis Majid. Islam Agama Peradaban: Membangun, Makna dan Relevansi Islam dalam Sejarah (Jakarta Yayasan Paramadina, 1995),h.94

${ }^{15}$ M. Amin Syukur, Menggugat Tasawuf: Sufisme dan Tanggung Jawab Sosial Abad 21, (Yogyakarta: Pustaka Pelajar, 1999), h. 97

${ }^{16}$ Harun Nasution, Filsafat dan Mistisisme dalam Islam (Jakarta:Bulan Bintang, 1973), h.8.
} 
terhadap para wali-sufi dan kuburannya atau tempat-tempat lain yang dianggap kramat-suci. Fenomena ini didasari fanatisme berlebihan, yang mengakibatkan runtuhnya iman dan menghancurkan basis tauhidullah, bisa dilihat jelas terjadi di Saudi Arabia sebelum munculnya gerakan Wahabi abad ke-18. Pola sikap ini banyak diilhami oleh Ibn Taimiyyah. ${ }^{17}$ Ketiga, menolak ajaran wahdah al-wujud. Pemahaman ini kontroversial dengan pemahaman orang awam dan ulama" fikih. Dalam neo-sufisme, konsep ini lebih dipahami sebagai kerangka transendensi Tuhan sehingga tetap sebagai Tuhan yang Khaliq. Keempat, penolakan terhadap fanatisme murid kepada sang guru atau mursyid. Dalam tasawuf lama terdapat pandangan bahwa hanya dengan kepatuhan dan loyalitas mutlak terhadap guru, sang murid akan mecapai kemajuan spiritual atau maqam tertinggi, hal ini sudah menjadi kepercayaan mengakar. Dalam neo-sufisme, murid tidak harus memenuhi perintah dan ajaran sang guru jika jelas-jelas bertentangan dengan syarieeat, bahkan murid berhak dan harus melawannya. Dengan demikian, dalam neo-sufisme, hubungan guru dan murid berlandaskan pada komitmen sosial dan moral akhlak yang harus memiliki kesesuaian dengan al-Quran dan alSunnah. Kelima, dalam dimensi neo-sufisme, yang diposisikan sebagai syekh tarekat adalah langsung Nabi Saw., bukan para awliya atau pendiri-pendiri tarekat. Dengan demikian neosufisme hendak untuk menempatkan Nabi Saw. sebagai pendiri tarekat yang kemudian dijadikan sebagai teladan dalam kegiatan berfikir, berdzikir dan suri tauladan dalam hal apapun. Keenam, menciptakan organisasi massa yang terstruktur dan tersentralisasi secara cukup hierarkis dibawah otoritas pendiri tarekat dan para khalifah, namun masih berorientasi komunal atau sosial. Maka neo-sufisme mempelajari tasawuf berarti melakukan inisiasi atau masuk dalam organisasi massa. Ketujuh, menitik tekankan khusus pada kajian hadist atau sunnah yang betul-betul shahih, terutama tema terkait dengan memberi pengaruh pada rekonstruksi sosial-moral masyarakat, dari pada hanya ketetapan hukum fikih. Kedelapan, menolak taklid dan penegasan hak individu muslim melakukan ijtihad. Maka neo-sufisme berupaya mendorong orang muslim untuk mempunyai kapasitas keilmuan dan kemampuan berijtihad dari pada sekedar taklid pada ulama tampa reserve. Kesembilan, kesediaan berpolitik dan heroik patriotisme militerian untuk membela Islam. ${ }^{18}$ Jika tasawuf lama cenderung uzlah menghadapi realita sosial yang tidak baik dalam pertumbuhan keislaman,

\footnotetext{
${ }^{17}$ Fazlurrahman. Islam, h. 196

${ }^{18}$ Dalam sejarah kemerdekaan Indonesia, para ulama dan gerakan tasawuf memiliki andil besar melawan kolonial penjajah pada waktu itu membuat perlawanan untuk pembebasan dan kemerdekaan bangsa. Lebih lengkapnya lihat Sartono Kartodirdjo, Peasant's Revolt of Banten in 1888, (Den Haag: Martinus Nijhoff, 1966)
} 
maka beda halnya dengan neo-sufisme yang dengan karakter aktifisnya siap menghadapi tantangan dan memberikan respos perubahan konstruktif dan positif melawan ekspansi imperialisme Barat, terutama pada abad ke-18.

.Modernisme yang berkembang di Barat telah melahirkan pandangan hidup mekanistik dan atomistik. Hal ini terbukti dengan maju dan berkembangnya industrialisasi dan kemajuan tehnologi. Dilihat dari berbagai dampak positifnya, modernisme juga melahirkan perombakan pola kognitif manusia. Mekanisme kehidupan manusia berubah menjadi materi oriented dan berlalu mementingkan aspek lahiriah saja. Lambat laun, hal tersebut menjadikan manusia kehilangan jati diri, seni menjalani hidup untuk saling menghormati, tolong menolong dan dalam tingkat yang paling krusial kehilangan identitas yang berdampak menghilangkan nilai kemanusiaan. Hingga di sinilah, aspek bathiniyah manusia sudah sangat nampak sangat dibutuhkan, yang mampu memberikan siraman spiritual hati manusia yang gersang berada dalam keterasingan eksistensi dan dunianya sendiri. Modernisasi memberikan tantangan tersendiri dari agama atau relegiusitas, namun tidak bisa "menghilangkan" agama dari muka bumi ini. ${ }^{19}$

Karena semakin seseorang terbentur dalam kebuntuan makna hidup, maka ia akan semakin rajin mencari jawaban dari keterasingannya dan berupaya menemukan spiritualitas jati dirinya. Di silah tasawuf akan memainkan peran yang sangat signifikan menyuburkan area esoteris atau bathiniyah. Peran tasawuf sebagai solusi yang mampu menghadirkan jawaban dari persoalan dalam kehidupan moderen merupakan kontribusi yang bernilai mahal. Maka tasawuf dengan model neo-sufisme sesungguhnya merupakan bentuk esoteerisme atau penghayatan batini yang menghendaki hidup aktif dan terlibat dalam pembentukan sosial masyarakat, bukan hanya ingin mencapai kesolehan individu, namun lebih dari pada itu, terbentuknya tatanan kesolehan sosial yang universal. Hal itu hanya bisa diperoleh dengan penghayatan sikap keagamaan yang positif dalam memahami agama yang memberikan porsi seimbang antara kosmos dunia dan akhirat. ${ }^{20}$

Dengan uraian di atas, maka corak dan karakter neo-sufisme yang secara eksistensial adalah dimensi esoterisme Islam, menjadi sangat dibutuhkan oleh orang mederen

\footnotetext{
${ }^{19}$ Amin Syukur, Tasawuf dan Krisis, (Yogyakarta: Pustaka Pelajar,2001), hlm. 45. Lihat pula Azyumardi Azra, Neo-Sufisme dan Masa Depannya, dalam Muhammad Wayuni Nafis, (ed.). Rekonstruksi dan Renungan Releguis Islam, (Jakarta: Paramadina, 1996), hlm. 288.

${ }^{20}$ Abdul Munir Mulkhan, Neo-Sufisme dan Pudarnya Fundamentalisme di Pedesaan, (Yogya-karta: UII Press, 2000), hlm. 187. Lihat pula Said Aqil Siradj, Tasawuf Sebagai Kritik Sosial: Mengedepankan Islam Sebagai Inspirasi Bukan Aspirasi, (Bandung: Mizan, 2006).
} 
FARABI

Jurnal Pemikiran Konstruktif Bidang Filsafat dan Dakwah

ISSN $1907-0993$

E ISSN $2442-8264$

Vol. 18 No. 2, Desember 2018

dewasa ini, yang telah kehilangan penghayatan batinnya. Sekaligus tidak usah takut ketika menjadi pengamalnya akan kehilangan partisipasi dalam kompetisi duniawi, karena neosufisme menekankan sikap aktifisme dalam berfikir dan bertindak, bukan malah menjauh sebagaimana dalam tasawuf "ektrem". Tidak sulit kiranya untuk meramalkan, prospek neosufisme sangat pesat untuk berkembang dikemudian hari, terlebih ketika klimaks modernisasi sudah mencapai puncaknya. Bisa dilihat sekarang ini di perkotaan, fenomena maraknya bermunculan komunitas yang mengatas namakan agama dan aliran.

\section{KESIMPULAN}

Neo-sufisme mencoba untuk mengkombinasikan pola tasawuf yang melibatkan dua kekuatan berdimensi eksoterik dan esoterik dalam Islam. Eksistensi neo-sufisme dikombinasikan dalam satu bingkai pandangan dunia secara aktif dan penganjuran sikaphidup dalam mengambil bagian solusi bagi seluruh aspek kehidupan masyarakat. Dengan demikian, maka untuk masa sekarang tasawuf dituntut untuk mengarahkan orientasi dan melaksanakan tanggung jawab baru, yaitu menyempurnakan moral individual ke moral struktural sosial dengan cara melakukan gerak perubahan: (1) dari jiwa ke tubuh, (2) dari rohani ke jasmani, (3) dari etika individual ke etika sosial, (4) dari meditasi ke tindakan terbuka, (5) dari isolasi ke gerakan sosial-politik, (6) dari pasif ke aktif, (7) dari kesatuan hayal ke persatuan nyata (relaitas). Dengan demikian Neo-sufisme menciptakan hubungan harmonis antara tasawuf dengan kekayaan dan kemoderenan, perpaduan keduanya justru akan melahirkan kekuatan besar dalam merubah dunia lebih baik. Neo-sufisme melakukannya dengan cara mencampurkan hal-hal keduniawian dengan subtansi aktifisme spiritualitas yang akan memberikan makna bagi nilai hidup dan manusia. Dengan kata lain, bahwa neo-sufisme menginginkan keselarasan antara penghayatan pengamalan tasawuf dengan syarieeah.

\section{DAFTAR PUSTAKA}

Amin Syukur, Tasawuf dan Krisis, (Yogyakarta: Pustaka Pelajar, 2001)

Azyumardi Azra, Neo-Sufisme dan Masa Depannya, dalam Muhammad Wayuni Nafis, (ed.). Rekonstruksi dan Renungan Releguis Islam, (Jakarta: Paramadina, 1996

Abdul Munir Mulkhan, Neo-Sufisme dan Pudarnya Fundamentalisme di Pedesaan, Yogyakarta: UII Press, 2000

Abd A"la, Dari Neomodernisme ke Islam Liberal: Jejak Fazlurrahman dalam Wacana Islam di Indonesia Jakarta: Paramadina, 2003. 
Fazlur Rahman, Islam and Modernity: Tranformation of an Intellectual Tradition (Chicago and London: University of Chicago Press, 1988

Ghufron A. Mas ${ }^{e e}$ adi, Pemikiran Fazlur Rahman.

Harun Nasution ensiklopedi Islam Indonesia, Jakarta, Djembatan: 1992

---------------, Filsafat dan Mistisisme dalam Islam (Jakarta: Bulan Bintang, 1973

Hamka, Tasawuf Modern, (Jakarta: Pustaka Panji Masyarakat, 1988

Kasmuri selamat dan Ihsan Sanusi, Akhlak Tasawuf: Upaya Meraih Kehalusan Budi dan kedekatan Ilahi Jakarta Kalam Mulia, 2012),

Said Aqil Siradj, Tasawuf Sebagai Kritik Sosial: Mengedepankan Islam Sebagai Inspirasi Bukan Aspirasi, (Bandung: Mizan, 2006

Said Agil Husain Al-Munawar, Al-Quran Membangun Tradisi Kesalehan Hakiki (Cet. III; Jakarta: Ciputat Press, 2004

Martin dan Julia, Urban Sufism, (Jakarta : Raja Grafindo Persada, 2008

M. Amin Syukur, Menggugat Tasawuf: Sufisme dan Tanggung Jawab Sosial Abad 21, (Yogyakarta: Pustaka Pelajar, 1999

Nurcholis Majid. Islam Agama Peradaban: Membangun, Makna dan Relevansi Islam dalam Sejarah Jakarta Yayasan Paramadina, 1995

Pusat Bahasa Departemen Pendidikan Nasional. Kamus Besar Bahasa Indonesia, (edisi III), (Jakarta: Balai Pustaka, 2005

Wahyuni Eka Putri, "Hermeneutika Hadis Fazlurrahman" dalam Syahiron Syamsudin (ed.) Hermeutika Al-Qur'an dan Hadis (Yogyakarta, Elsaq Press, 2010

Hartono Kartodirdjo, Peasant's Revolt of Banten in 1888, (Den Haag: Martinus Nijhoff, 1966) 